\title{
The Silent Revolution: Decollectivization from Below during the Cultural Revolution
}

\author{
Frank Dikötter ${ }^{*}$
}

\begin{abstract}
This article uses fresh archival evidence to point at a rarely noticed phenomenon, namely the undermining of the planned economy by a myriad of dispersed acts of resistance during the last years of the Cultural Revolution. Villagers reconnected with the market in some of the poorest places in the hinterland as well as in better-off regions along the coast. This silent, structural revolution often involved the quiet acquiescence, if not active cooperation, of local cadres. In conclusion, the article suggests that if there was an architect of economic reforms, it was the people and not Deng Xiaoping: as with his counterparts in Central Europe and the Soviet Union, Deng had little choice but to go along with the flow.
\end{abstract}

Keywords: China; Cultural Revolution; planned economy; decollectivization; market

As Istvan Rév, a historian of Hungary, noted some years ago, social scientists are attracted by political movements that have concrete, articulated aims. Historical actors must possess "political consciousness," or else they are unlikely to be granted much significance. "They must be able to write manifestoes, to leave written documents behind them; they must be capable of giving a compact political analysis to the scientist who comes to interview them." The strategies of survival that can to be found in the countryside in planned economies - pilfering, lying, slacking, stealing, bartering, trading - are seen to be "pre-political," or merely reactive, if not downright "reactionary" in trying to revive the old order. They are assumed to have few long-lasting consequences. But, as Rév pointed out, through endless acts of resistance, villagers in the countryside forced the regime to change. "From a closer look, all the important and long-lasting economic and social reforms in all the Central European countries appear as nothing but the legalization of already existing illegal and semilegal practices. What seems to be the work of the professional reformers (experimentation with and revitalization of the market, the coexistence of the small and the big 
in agriculture, the convergence of the first and the second economies, the granting of concessions to small-scale private enterprises, the liberalization of the planning mechanism) is in fact the consequence of continuous atomized resistance."

What Rév means by "atomized resistance" is that in the Soviet Union and in Central Europe, once communist parties had liquidated everything that stood in between the state and the individual, from civic associations and worker unions to private clubs, almost everything became a potential political issue. Instead of smashing all opposition, it became dispersed, "hidden but present everywhere."” The use of terror to atomize society into isolated individuals did not result in complete control by the state over all, but in the creation of endless potential enemies. Bringing a chicken to market or slacking at work was no longer an economic act but a subversive, political one. Concern with the family was not a sign of love but a worrisome remnant of bourgeois ideology. Every act of survival in the countryside came to be understood as an anti-party, capitalist practice. In other words, the expansion of coercion and terror created more, not less, room for resistance. But the state was not equipped to fight millions of individual acts of subversion, and in any event was too inflexible to defend itself against challenges from all directions. It had to bend or risk breaking. It went along, reforming the system by legalizing the practices surreptitiously introduced by the villagers.

Much of this transformation from below has escaped the gaze of social scientists, and not only because atomized resistance lacked overt political organization. It also left few traces. Resistance in Central Europe was silent, whether villagers quietly hid the grain, stole food from the fields on the sly or traded it on the black market. "The technique of the resistance is the nonevent, the means is the nonobject, the actors are anonymous." 3

Kate Zhou has observed a very similar phenomenon in China. Throughout the 1980s, as her pioneering book How the Farmers Changed China demonstrates, farmers leeched away the economic dominance of the state and replaced it with their own initiative and ingenuity. There was no organized confrontation, which no communist party anywhere would have tolerated, but a myriad of daily acts of quiet defiance and endless subterfuge instead, which left the cadres defenceless. Without leaders, without overt opposition and without an explicit ideology, villagers undertook a silent structural revolution, as the aggregate effect of many millions of ordinary people changed the economic and political landscape for ever. In short, if there was an architect of economic reforms, it was the people and not Deng Xiaoping 邓小平, who had little choice but to go along with the flow, as did his counterparts in Central Europe and the Soviet Union. ${ }^{4}$

1 Rév 1987, 341-45; I would like to thank Patricia Thornton for having brought the work of Istvan Rév to my attention.

2 Ibid., 347.

3 Ibid., 349.

4 Zhou 1996, 15. 
One of the difficulties that historians of communism face is finding evidence of a revolution that produced no sounds. But, as the work of Gábor T. Rittersporn and others has illustrated in the case of the Soviet Union, there is plenty of telling material that can be teased out of the archives. ${ }^{5}$ In the case of China, while access to Party archives on the Mao era is checkered, there are still more than enough clues to indicate that a silent revolution started a decade earlier than Kate Zhou has suggested, namely during the Cultural Revolution.

In fact, as Kate Zhou herself has indicated in her book, resistance against collectivization started as early as the 1950s, and reached a peak during Mao's Great Famine. In an odd twist, the attempt to replace individual rewards with moral incentives during the Great Leap Forward produced a nation of entrepreneurs. People did not simply wait to starve to death. In a society in disintegration, they resorted to every means available to survive. So destructive was radical collectivization that at every level the population tried to circumvent, undermine or exploit the master plan, covertly giving full scope to the profit motive that the Party tried to eliminate. As the catastrophe unfolded, claiming tens of millions of victims, the very survival of an ordinary person came to depend on the ability to lie, charm, hide, steal, cheat, pilfer, forage, smuggle, trick, manipulate or otherwise outwit the state. ${ }^{6}$

Much of this covert behaviour came under scrutiny during the "socialist education" campaign from 1962 to 1966, as the state tried to shore up the socialist economy and stamp out anything that smacked of "capitalism." But, with the onset of the Cultural Revolution, parts of the countryside again used the chaos to reclaim some of the freedoms they had lost under communism, expanding their private plots, taking produce to market, opening underground factories or leaving the people's communes to seek their fortune in the city. The trend was substantial enough in some villages to amount to decollectivization.

But yet again, the pendulum swung back, as revolutionary committees in 1968 effectively turned the country into a military dictatorship, using the threat of war with the Soviet Union a year later to impose much greater control over the countryside. The "learn from Dazhai" campaign heralded a return to the Great Leap Forward by promising prosperity and abundance to all those who laboured the land collectively. In their eagerness to radically collectivize the economy, some cadres abolished private plots altogether and even slaughtered private animals. In Zhejiang province as a whole, a quarter of all production teams reverted to the extreme collectivization of the Great Leap Forward by handing over responsibility for accounting to the brigade, the second tier of organization in the countryside, placed between the people's commune and the team. It meant that the villagers lost control over income distribution. Simply gathering firewood or raising a buffalo was now denounced as "capitalist."7 In Gansu province, private

7 Zhejiang Provincial Archives, 8 September 1971, J116-25-159, 160-62; Zhejiang Provincial Archives, 17 March 1972, J116-25-250, 73-76. 
plots covering a total surface of more than 77,000 hectares were returned to the collectives, which accounted for roughly a third of all private holdings. In some counties, one report noted, "all private plots have been entirely taken back."

The tool used by the revolutionary committees to enforce the Dazhai 大寨 model was a widespread campaign against graft, speculation and waste, usually referred to as the "three antis." Across the country, the campaign was directed at millions of ordinary people who had quietly exploited the chaos of the Cultural Revolution to advance their own economic freedoms. From poor villagers who had enlarged their private plots to ordinary people who had bought some vegetables from the black market, the campaign crushed those accused of "following the capitalist road." Numbers can be numbing but they indicate the extent of the persecution. In Hubei, such "capitalist roaders" represented 447,000 out of the 736,000 victims harassed by the authorities from February 1970 to October 1971. They made up 169,000 of the total of 225,000 suspects taken to task in the three first months of the campaign in Gansu. ${ }^{9}$

This campaign was paralleled by an equally wide-ranging strike against "counter-revolutionary activities," defined in such a way as to encompass almost anything deemed to be "destructive." Much more evidence is needed to capture the precise contours of the "one strike" and "three antis" campaigns, which varied enormously from place to place, but in provinces like Hubei and Gansu they implicated roughly one in every 50 people. Very few of the culprits were shot, and many got away with a reprimand or a spell in a re-education camp. In sharp contrast to the purges that claimed several million victims in the early years of the People's Republic when the regime tried to eliminate all organizations standing in between the state and the individual, the point of the "one strike" and "three antis" campaigns was not to physically eliminate real or imagined enemies but rather to intimidate the greatest number of people possible. The objective was to produce a docile population by turning almost every act and every utterance into a potential crime.

The result was "atomized resistance," to borrow Istvan Rév's expression. But not only did the regime create millions of new enemies by turning virtually every minor act of defiance into a political crime, it also suffered a huge blow with the death of Lin Biao 林彪 in September 1971. The Lin Biao incident drastically undermined the role of the military and forced Mao to turn to those Party officials denounced as "capitalist roaders" during the height of the Cultural Revolution; however, the power and prestige they once wielded was gone. If the Great Leap Forward had destroyed the credibility of the Party, the Cultural Revolution undermined its very organization. September 1971, SZ139-2-114, n.p.; Gansu Provincial Archives, 6 May 1970, 129-6-45, 46-47. 
The extent to which ordinary villagers reconnected with the market in the last five years of the Chairman's reign is amply illustrated by evidence from the archives. Even in the very heart of the revolution, amidst the dusty, sandstone-coloured hills of northern Shaanxi where the Communist Party had established its headquarters during the Second World War, capitalism seemed rampant by 1974. The "Yan'an spirit" championed selfless dedication to the greater good, but on the ground, local people embraced the market in order to pull themselves out of poverty. One village in Yan'an 延安 even abandoned any attempt to wrench food from the arid and parched soil and specialized in selling pork instead. In order to fulfil their quota of grain deliveries to the state, they used the profit from their meat business to buy back corn from the market. Local cadres supervised the entire operation. Few in the village seemed to have any interest in politics. More than three years after the demise of Lin Biao, posters of the erstwhile heir apparent still fluttered in the wind. Slogans painted on outside walls were fading, and dated mostly from 1969. ${ }^{10}$

Yan'an was not alone in taking to the market. Entire people's communes in Luonan 洛南, less than two hours away from Xi'an by bus, had divided up all collective assets and handed responsibility for production back to individual families. Many villagers abandoned two decades of monoculture, imposed by a state keen on producing grain to feed the cities and barter on the international market, and cultivated crops that performed well on the black market. Some rented out their plots and went to the city instead, working in underground factories and sending back remittances to the village. Other freedoms flourished. The head of one production team, instead of adorning his front door with slogans exalting Chairman Mao, displayed couplets composed by a Tang dynasty emperor. Traditional geomancy, decried as superstition since liberation, seemed to matter more than the latest Party directives, which everybody ignored. Spirit mediums and fortune tellers did the rounds. ${ }^{11}$

In Pucheng 蒲城, further to the north of Xi'an, some cadres also stood back and allowed the villagers to go about their business. Here, too, propitious couplets in traditional calligraphy largely displaced loud slogans in brash red, and here too, Party officials expressed little interest in reading newspapers, let alone keeping up with the Party line. "Not one Party meeting has been called, and not one of the prescribed works of Marx, Lenin and Chairman Mao has been studied," deplored one report. In some production brigades, telephone conferences were not a realistic prospect, since the lines had been cut down and were used by the villagers to dry sweet potatoes. Instead of working for the collectives, people with any kind of expertise offered their services to the highest bidder. There were doctors who gave private consultations for a fee. There were selfemployed artisans. Chen Hongru 陈鸿儒, classified as a "rich peasant" and a "counter-revolutionary" to boot, worked as a carpenter on the black market, 
helping out production teams during the busy season for no less than 25 work points a day, more than twice the amount a hard-working male adult could earn in a collective. ${ }^{12}$

This all took place in Shaanxi, where millions went hungry, some of them eating mud or stripping bark from trees. Necessity is the proverbial mother of invention, and the overlap between sheer destitution and the entrepreneurial spirit could be found elsewhere. In many cases, as the example of Yan'an illustrates, the local cadres took a lead by distributing the land to the farmers. Sometimes, a deal was struck between representatives of the state and those who tilled the land, as the fiction of collective ownership was preserved by turning over a percentage of the crop to Party officials. Bribery often greased the wheels of free enterprise, as the villagers paid the cadres to look the other way.

The return to market principles was facilitated by divisions at the top. Throughout the Cultural Revolution, partisan wrangling and factional infighting among the leadership had resulted in constant changes in government policy. On the ground, villagers were often subject to the ebb and flow of radical politics, as the precise contours of the collective economy, from the size of private plots to the number of animals that a family could own, shifted from one campaign to the next. They were also at the mercy of the local cadres, who had some scope to interpret or negotiate the constantly changing rules of the game.

This became particularly prominent after the North China Agricultural Conference in the summer of 1970, as Zhou Enlai 周恩来 tried to move away from the destructive effects of extreme collectivization. In subsequent months, numerous articles appeared in the press stressing the right of villagers to tend private plots, the importance of local peasant markets and the contribution of cash crops to the collective economy. These measures did not go beyond what was introduced after the catastrophe of the Great Leap Forward. Private plots, for instance, were extremely limited in size and could only be cultivated by villagers in their spare time once all collective duties had been completed, while a great variety of products could not be traded in local markets, including all those over which the state had a monopoly, from cotton, edible oil, meat and grain to tobacco and timber. Still, the more extreme interpretations of the "learn from Dazhai" campaign were softened. On 26 December 1971, precisely seven years after Chen Yonggui 陈永贵 had shared a meal with Chairman Mao to launch the slogan, "In agriculture, learn from Dazhai" (nongye xue dazhai 农业学大寨), the People's Daily even cautioned against "blindly learning from Dazhai." 13

The countryside was allowed to diversify its production and establish small industries, a policy also heralded by the premier at the 1970 North China Agricultural Conference. The idea was that China should "walk on two legs," as rural enterprises would support agricultural development, for instance by

12 Shaanxi Provincial Archives, 6 February 1975, 123-71-209, 34-48.

13 Zweig 1989, 61-62. In communist parlance, these measures were referred to as the "sixty articles." 
producing farming tools, chemical fertilizers and cement. But this, too, was hardly a new departure. In Dazhai, the peasants working under Chen Yonggui operated a brick kiln, a noodle factory and a bauxite mine, as agriculture and industry merged to advance the collective cause. The whole idea of "walking on two legs" dated from the Great Leap Forward, when Chairman Mao thought that his country could overtake its competitors by relocating industry to the countryside, liberating the productive potential of every peasant in huge people's communes. The rural enterprises that the state encouraged remained firmly under collective leadership. ${ }^{14}$

Given these conflicting messages from the top, very different approaches appeared throughout the countryside, as overzealous cadres continued to impose radical collectivization and ban private plots in some places, whilst elsewhere villagers were allowed more scope for private initiatives. But, most of all, as the standing of the Party suffered a blow in the aftermath of the Lin Biao affair, some cadres started deliberately twisting and bending various state directives, taking them far beyond what the leadership intended. As one village official put it, the rural cadres, "after the continuous flip-flop of government policies and after their repeated humiliations in public during struggle sessions," lost interest in politics. They devoted their energy to production instead. Some of them opened up every portion of collective property to negotiation, from control over the pigsty, the fish pond and the forest, to the exact dimensions of individual plots. They allowed a black market to thrive in the knowledge that their own livelihoods, including the food they ate, depended on free trade. They encouraged the villagers to leave the collectives and strike out on their own. ${ }^{15}$

Much as need ruled large parts of the country, prompting villagers to rely on their own wits to pull themselves out of destitution, opportunity also played an important role. Some villages were better off than others. They capitalized on their advantages to improve their collective lot, whether these advantages were proximity to transportation routes, abundant fish and wildlife, a regular water supply, fertile soil, a level terrain for farming or access to sources of energy such as coal and wood.

Wealthy regions joined those mired in poverty in a silent revolution that subverted the planned economy. In villages along the southern coast, people raised ducks, kept bees, grew fish, baked bricks and cut timber, always in the name of the collective. By late 1971, in the county of Xinchang 新昌, Zhejiang, which housed a population of roughly a quarter of a million people, some two-thirds of all villagers were independent - or "go-it-aloners" in the parlance of the

14 See "Economic situation in China," 1971, Public Records Office, London, FCO 21-841; see also Kueh 2006.

15 Huang 1989, 109-110. There are clear parallels with Zhou 1996, 55. See also Thaxton 2008, 278; Kelliher 1992. 
time. Much of this was done with the tacit consent of the local authorities, who rented the land to individual households in exchange for a portion of the crop. ${ }^{16}$ A year before Mao Zedong's death, the habit of leaving the collectives to try one's luck on private land or in underground factories was described as "widespread" throughout the province. Wenzhou 温州 took the trend to the extreme, as private capitalism flourished in the city and its isolated delta despite repeated harassment from the government.

Nowhere was this trend more evident than in Guangdong, a subtropical province with plenty of light, heat and water, as well as abundant waterways and a long coastline ideal for economic growth. Markets were everywhere. In Qingyuan 清远, virtually every commodity normally banned from the market by virtue of a government monopoly was openly on sale, including grain, peanuts, oil and tobacco. Business was swift. It took a team of five youths sent by the village elders no more than half an hour to dispose of 200 kilos of grain. ${ }^{17}$

Further inland, in the county of Puning 普宁, some 30 markets covered the needs of more than a million people. They attracted local farmers, artisans and traders, each with their vendible goods on hand, back or cart. Pedlars offered colourful illustrations from traditional operas, books from the imperial and republican eras and collections of traditional poetry that had escaped the clutches of the Red Guards. There were itinerant doctors offering their services. Storytellers used wooden clappers to mark the most dramatic moments of their stories. Blind people sang traditional folk songs for a few alms. Touts stood outside local restaurants selling ration coupons. Many hundreds came by bicycle from other parts of the province each day. In some markets, organized gangs travelled up and down the coast, going all the way to Shanghai to trade in prohibited goods. A few went as far as Jiangxi to procure tractors in response to requests from local villages keen to mechanize. ${ }^{18}$

Here, too, the local cadres were reluctant to interfere. Some even encouraged the villagers to abandon grain production despite it being mandated by the state and pursue more profitable crops instead. Government agents failed to stamp out illegal trading, as "they are only concerned with collecting fees, and do not care about government policy," the authors of one detailed investigation deplored. Small pedlars could be suppressed, the report continued, but "the cadres and the villagers will have no vegetables to eat." 19

The market exploited the difference between the fixed price set by the command economy for agricultural products and the higher amounts ordinary people were prepared to pay. A difference of 100 per cent was common, but some commodities, for instance soy beans, reached 500 per cent, meaning that the state

16 The expression was jietian daohu, meaning to "lend the land to individual households": Zhejiang Provincial Archives, 8 September 1971, J116-25-159, 155; White 1998, 120-21.

17 Guangdong Provincial Archives, 1 November 1975, 294-A2.14-6, 52.

18 Guangdong Provincial Archives, 20 December 1973, 296-A2.1-51, 44-53; Guangdong Provincial Archives, 20 March 1974, 294-A2.13-8, 1-28.

19 Guangdong Provincial Archives, 20 December 1973, 296-A2.1-51, 44-53. 
procured them at 0.44 yuan per kilo when the same amount could fetch 2.2 yuan on the market. ${ }^{20}$ As Istvan Rév has noted for Central Europe, the higher the prices on the black market, the less incentive there is to hand over produce to the state. The more successful villagers were, the more incentive they had to resist. "It was the invisible hand of resistance, the micro actions, having a profound effect on the macro sphere of politics." 21

The market in Puning, like elsewhere, thrived because the command economy could not deliver sufficient goods to meet the demands of ordinary people. Widespread shortages forced prices up, stimulating private enterprise. Timber was a case in point. By 1973, fir was ten times more expensive than it had been at the beginning of the Cultural Revolution in 1966. Across the county, there were thousands of unfinished houses, abandoned for lack of timber. Some people were willing to pay a premium on the black market. Across the mountains in the north of Guangdong province, there was the random felling of trees. The trade was not limited to a few farmers bringing planks to market on their bicycle carts: there were hundreds of factories in Lechang 乐昌, Qingyuan and Huaiji 怀集 illegally trading in timber, up to 70,000 cubic metres in 1973 according to one estimate. ${ }^{22}$

Guangdong had another asset that helped some people sidestep the planned economy. Not far away from the Pearl River Delta, counties like Kaiping 开平 and Taishan 台山 were traditionally dominated by emigration overseas. Before liberation, whole villages had displayed ostentatious mansions built by returned migrants, including thousands of large, fortified towers influenced by foreign architecture and furnished with everything from flushing toilets and marble tiles to Gothic battlements and turrets. Relations between these emigrant communities and the Communist Party were bad, and in 1952 many bore the brunt of a bloody campaign of land reform. Years later, at the height of the Cultural Revolution, when people lived and died by their class background, many were denounced as "spies," "traitors" and "counter-revolutionaries," further disrupting links with overseas communities. But, after 1970, goods and remittances once again started to pour across the border. By 1974, the amount of money reaching the villagers from overseas was twice as high as in 1965. Families with overseas connections had been the first to suffer from the onslaught of the Cultural Revolution, and now they were the first to emerge from uniform poverty. They used foreign remittances to tackle a housing crisis created by years of neglect if not wilful assault on anything bearing the hallmark of imperialism. In Taishan and elsewhere in the region, they bought up steel, timber and concrete. Chen Jijin 陈季金 shared a mud hovel with his family of eight. He was

20 Ibid.

21 Rév 1987, 348.

22 Report from Guangdong Provincial Revolutionary Committee, 26 November 1973, Shandong Provincial Archives, A47-2-247, 37-39; Guangdong Provincial Archives, 20 December 1973, 296-A2.1-51, 44-53. 
waiting for a remittance of 20,000 yuan to build a new house - a sum representing the combined annual salaries of 30 qualified factory workers. ${ }^{23}$

The number of parcels received from abroad also went up. In Guangzhou, the provincial capital, more than 200,000 packages had accumulated in 1972, but the backlog was cleared by the end of the year. They contained mainly clothes and edible oil, reflecting local market shortages. Other commodities included beans, bulbs, matches and medicine. Some of them found their way onto the black market. ${ }^{24}$

A measure of decollectivization could also be seen in other provinces. In Sichuan, a huge inland province which had suffered terribly during the Great Leap Famine before being wrecked during the Cultural Revolution, the land was rented to the farmers in the early 1970s. The desire to own land was driven from below and only ratified by local authorities much later. ${ }^{25}$

Returning the land to the cultivators was but one aspect of a silent revolution in the countryside. Some wealthier villages not only planted profitable crops for the market but also began establishing local factories. This was common in many parts of Guangdong. In Chaoan 潮安, just outside Shantou 汕头, where entire villages had been reduced to poverty after embroidery was declared to be "feudal" at the height of the Cultural Revolution, historic links with the overseas community were revived after the Ministry of Light Industry lifted the trading restrictions in 1972. ${ }^{26}$ Two years later, up to half of the women in some villages once again specialized in drawn work and embroidery. Their output was worth 1.3 million yuan on the foreign market. Others turned to manufacturing hardware and tools. But while some of these village enterprises were collectively owned, many merely used the appearance of a collective to run a business entirely along private lines. A good example was Dongli Village 东里村, where all but 40 of the 420 families were members of a nail factory. They worked from home and were paid by the piece. All the profits went straight to the individual workers, who were also responsible for finding the raw material. Some bought it from street pedlars, others obtained recycled iron from the black market, and a few went to Shantou to buy in bulk. A good worker made 5 to 10 yuan a day, the equivalent of what an ordinary farmer made by working in a commune for an entire month. ${ }^{27}$

The village enterprises contributed to the market in more than one way. They not only sold their wares through intermediaries but also used their earnings to buy grain and fodder for their pigs, along with imported goods that the planned

23 Guangdong Provincial Archives, 26 September 1975, 253-2-183, 95-99.

24 Ibid.; Report from the Ministry for Trade, 13 December 1972, Hebei Provincial Archives, 919-3-100, 37.

25 Bramall 1995.

26 Report from the Ministry for Light Industry, 13 December 1972, Hebei Provincial Archives, 919-3-100, $17-21$.

27 Guangdong Provincial Archives, 20 March 1974, 294-A2.13-8, 1-28. 
economy could not provide, such as fish oil or aspirin. They sent purchasing agents to compete with the state sector for the scarce resources needed to run their businesses, buying up coal, steel and iron. ${ }^{28}$

These examples come from Guangdong, but rural enterprises were not limited to the south. In parts of Jiangsu, contracts were concluded between the production team and individual households as early as 1969, in blatant violation of the radical policies of the time. This process often began in regions where the land was unsuitable for agriculture. Along the coast, for instance, some villagers at first abandoned the sandy soil and switched to raising fish instead. They then gradually turned their attention to industry. In Chuansha 川沙, where villagers were mandated by the state to grow cotton, the industrial portion of total production increased from 54 per cent in 1970 to 74 per cent five years later, a rate of growth far superior to the years of "economic reform" after 1978. In contrast, in Songjiang 松江 county local leaders continued to obey the state's call for grain. ${ }^{29}$

The growth of cottage industries in the Yangtze Delta followed old manufacturing habits and trading routes that predated liberation. They were revived as soon as the hand of the state weakened. Much as Shantou had a long tradition in exporting embroideries to overseas markets, for many centuries the villages around Shanghai had specialized in household goods, ceramics, cloth, silk and other handicrafts. Mechanization spread from the late 19th century onwards, as simple devices for reeling silk, for instance, were incorporated into the village mills, diversifying production even further. Sophisticated guilds, chambers of commerce and banks in Shanghai, often with overseas connections, coordinated a flourishing trade. The Shanghai Silk Reeling Industry Trade Association, to name but one, promoted the production and commerce of silk in Shanghai, Jiangsu, Anhui and Zhejiang prior to being disbanded by the communists in 1949.

The extent to which rural industry reconnected with its past in the early 1970s is shown by statistics: in Jiangsu province as a whole, industry represented a mere 13 per cent of total output in the countryside in 1970, but a phenomenal 40 per cent by 1976 . These factories were often collective, if in name only. Tangqiao Village 塘桥村, with help from the cadres, established a metalworking factory with 25 employees in 1970. A year later, it set up a power plant as well as a cardboard box factory, several other metal shops and an animal feed processing plant. A brick factory followed in 1972, all of it in blatant defiance of the state's demand that the countryside grow grain and "learn from Dazhai." The village leaders now attracted political attention and started opening new enterprises under the umbrella of a "comprehensive factory." The facade of planned unity was abandoned the moment Chairman Mao died in 1976. ${ }^{30}$ 
There were also underground factories that dispensed altogether with the pretence of collective ownership. These, too, were run by village leaders. They had appeared during the Great Leap Forward, although many folded during the catastrophe that followed. The sociologist Fei Xiaotong 费孝通 wrote of these clandestine enterprises that "peasants did not mind what the nature of ownership was. The only thing they did mind was to keep up their livelihood." Some of them were run by individuals, who merely used the name - and often the accountant of the collective. In other words, they attached themselves to production teams and relied on state officials for protection. ${ }^{31}$

Officials in the higher echelons of power could do very little about the trend. In Shanghai, Zhang Chunqiao 张春桥 fulminated about the "sprouts of capitalism in the countryside." Others railed against the attack on the "dictatorship of the proletariat." There were periodic campaigns to "cut the tail of capitalism" but they were met with widespread sabotage, as villagers slaughtered their animals and diverted collective resources for their own use. Private firms went underground, at least temporarily till the storm blew over. In reality, outside some of the cities where the radical followers of the Chairman were well entrenched, large parts of the countryside were no longer within their reach. ${ }^{32}$

\section{$* * *$}

When the garden economy created by private plots and rented land produced a surplus, villagers sometimes got on their bicycles and went to the city to sell their vegetables, fruit, chickens, ducks and fish. A few took their produce from door to door, others gathered outside department stores, by railway stations or near the factory gates, sitting on curbs and spreading out their wares on the ground or on small card tables. They were regularly chased away by public security services, but they kept on coming back. Sometimes, the local authorities turned a blind eye, as people met at an agreed time to trade goods at makeshift bazaars. ${ }^{33}$

Villagers went even further in restoring the links that had tied the countryside to the cities. They migrated in large numbers, despite the restrictions imposed by the household registration system. During the Great Leap Forward, tens of millions of villagers had resettled in the cities, working in underground factories or on construction projects. Many were sent home during the famine but they kept on coming back, carrying out the dirty, dangerous or demeaning jobs that city dwellers were unwilling to do. By the early 1970s, many villages had a wellestablished tradition of migration, knowing how to evade agents of the state, where to seek employment in the city and how to look after family members left behind. Sometimes, the cadres themselves encouraged a form of chain migration by agreeing to take care of children and the elderly, as remittances from workers in the city contributed to the survival of the entire village. The migrants

31 Fei Xiaotong, as quoted in White 1998, 118.

32 White 1998, 120-21.

33 For good examples, see Thaxton 2008. 
continued to submit their quota of grain, either through relatives or by paying a fee directly to the village leader. ${ }^{34}$

Many millions evaded government control in the wake of the Lin Biao affair, seeping through the holes of the household registration system to settle inside the very heart of the city or along its periphery. Circles of relative wealth appeared around the cities, as pedlars and farmers moved to fringe areas where they cultivated vegetables or manufactured small goods to sell to urban residents. Some gave up on agriculture to set up food stalls or open small restaurants near the local markets.

Many lived in a twilight zone, constantly evading government control and running the risk of being sent back to their home villages, but large numbers managed to acquire the right to stay in the city. Not all of them were peasants. There were rural cadres keen to acquire urban residency, workers who had been sent to the Third Front and erstwhile city dwellers banned to the countryside after 1968. They pulled strings, offered bribes and pleaded with the authorities. Many of them were recruited by state enterprises, thereby allowing factory leaders to cut labour costs. Those who were formally allowed to stay brought over friends and relatives from the village.

The numbers were staggering and counteracted the efforts the state had made to curb the urban population in 1968-1969. In Shaanxi, major cities across the province grew by a quarter of a million people in 1970, and again by a third of a million the following year, reaching a total of 3.6 million. Once natural population growth and changes to the planned economy had been taken into account, it appeared that many were villagers, soldiers and cadres who had managed to bypass the restrictions imposed by the household registration system. ${ }^{35}$

It was the same elsewhere. In Hubei, the urban population grew by a mere third of a million between 1965 and 1970, but by half a million in the following two years. In 1972 alone, more than 300,000 people managed to acquire urban residency. A fifth of these permits were deemed to have been obtained fraudulently. There were also tens of thousands of people without any right of abode, including children and women married to urban residents. On top of this, in 1971 and 1972 half a million farmers settled in the periphery, on the very edge of urban areas, many of them moving in and out of the city during the day or working overnight shifts. ${ }^{36}$

Even in Beijing the authorities found it difficult to control the movement of people. By 1973, there were clusters of unemployed people openly wandering about the streets. Some were seeking work, others had secretly returned from their exile in the countryside, while whole groups of migrants were in transit, on their way to Heilongjiang. By one estimate, some 200,000 to 300,000 people

34 Shaanxi Provincial Archives, 20 August 1973, 123-71-70, 1-6.

35 Ibid.

36 Hubei Provincial Archives, 20 October 1972, SZ75-6-77, 12; Hubei Provincial Archives, 26 November 1973, SZ75-6-107, 58-59. See also Bonnin 2013. 
passed through the capital every day. The burden was such that a year later, the public security bureau employed more than 10,000 agents around the clock to try to keep the capital free of undesirable elements. ${ }^{37}$

Not only were more and more people ready to ignore the restrictions imposed on their freedom of movement by the household registration system but they were also happy to travel for free. In Harbin, the provincial capital of Heilongjiang, the local authorities estimated that 1.3 million people travelled without a ticket in 1973. A more precise example comes from Lanzhou, the capital of Gansu: during a random check carried out on 14 October 1973, two out of every three travellers were unable to produce a ticket on demand. About a third of a million people also scrambled on board freight trains in Lanzhou that same year. The express train from Shanghai to Urumqi, on the other hand, was "frequently" blocked by large groups of people who forced it to slow down and then boarded without a ticket. In parts of the country, travelling for free became a habit, as people argued that the "people's trains" were designed for "the people." In the station in Zhengzhou, a major railway hub in Henan, over a 1,000 travellers rushed to get on a train without a ticket each and every day. ${ }^{38}$

There was little that a weakened state could do to curtail the movement of millions of people - but there was a safety valve. In May 1970, the regime formally allowed some migrants to settle in Heilongjiang. With mountains covered in virgin larch, purple linden and red tree, the region had abundant natural resources that had already attracted people fleeing starvation in the wake of the Great Leap Forward. But, for the most part, the province remained an uninhabited wilderness. The state hoped that more riches would be tapped through voluntary resettlement - besides massive labour camps. The majority of migrants came from Shandong and Hebei, and many did not wait for the new state policy. In Zhaoyuan 招远 county alone, more than 2,000 people pulled up stakes in the single month of July 1969 and left in search of a better life in Heilongiiang. Some villages were almost emptied, as up to one-third of the locals voted with their feet, including the accountant and all the Party leaders. ${ }^{39}$

\section{Conclusion}

Throughout the country, from 1971 onwards people started quietly reconnecting with the past, whether they were local leaders who focused on economic growth or villagers who reconstituted popular markets that had existed long before liberation. Sometimes, a farmer merely pushed the boundaries of the planned

37 "Letter from embassy," 23 May 1973, Public Record Office, London, FCO 21-1089, 2; Report from the Ministry of Public Security, 30 August 1974, Shandong Provincial Archives, A47-2-247, 103-06.

38 Report from the State Council, 3 March 1974, Shandong Provincial Archives, A47-2-247, 26-29.

39 The directive was repeated in the following years; see Order from State Council, 5 June 1973, Hebei Provincial Archives, 919-3-100, 14-15; Report from the State Planning Committee, 25 July 1974, Shandong Provincial Archives, A47-2-247, 85-87; Shandong Provincial Archives, 19 August 1969, A47-21-100, 38-39. 
economy by bringing some corn to market or by spending more time on a private plot. In other cases, they were bolder - opening underground factories or speculating in commodities normally controlled by the state. But everywhere, in one way or another, millions upon millions of villagers surreptitiously reconnected with traditional practices, emboldened to take matters into their own hands by the failure of the Cultural Revolution. Even before Mao died in September 1976, large parts of the countryside had "gone capitalist."

The extent and depth of these liberal practices are difficult to gauge, as so much was done on the sly, but they thrived even more after the death of Mao. By 1979, many county leaders in Anhui had no choice but to allow families to cultivate the land. As one local leader put it, "household contracting was like an irresistible wave, spontaneously topping the limits we had placed, and it could not be suppressed or turned around." In Sichuan, too, local leaders found it difficult to contain the division of the land. Zhao Ziyang 赵紫阳, who had arrived in Sichuan in 1975 to take over as the head of the provincial Party committee, decided to go with the flow. ${ }^{40}$

By 1980, tens of thousands of local decisions had placed 40 per cent of Anhui production teams, 50 per cent of Guizhou teams and 60 per cent of Gansu teams under household contracts. Deng Xiaoping had neither the will nor the ability to fight the trend. As Kate Zhou has written, "When the government lifted restrictions, it did so only in recognition of the fact that the sea of unorganized farmers had already made them irrelevant."41

In the winter of 1982-1983, the people's communes were officially dissolved. It was the end of an era. The covert practices that had spread in the countryside in the last years of the Cultural Revolution now flourished, as villagers returned to family farming, cultivated crops that could be sold for a profit on the market, established privately owned shops or went to the cities to work in factories. Rural decollectivization, in turn, liberated even more labour in the countryside, fuelling a boom in village enterprises. Rural industry provided most of the country's double-digit growth, offsetting the inefficient performance of state-owned enterprises. In this great transformation, the villagers took centre stage. The rapid economic growth did not start in the cities with a trickle-down effect to the countryside, but flowed instead from the rural to the urban sector. The private entrepreneurs who transformed the economy were millions upon millions of ordinary villagers, and they effectively outmanoeuvred the state. If there was a great architect of economic reform, it was the people. ${ }^{42}$ But, as in Central Europe and the Soviet Union, there was a price to pay. By undermining the planned economy, villagers not only forced the regime to adapt, they also allowed it to last. 


\title{
Biographical note
}

Frank Dikötter is Chair Professor of Humanities at the University of Hong Kong. Before moving to Asia in 2006, he was professor of the modern history of China at SOAS, University of London. He has published ten books about the history of China, including Mao's Great Famine, which won the BBC Samuel Johnson Prize for Non-Fiction in 2011 and was translated into 13 languages. The Tragedy of Liberation: A History of the Chinese Revolution 19451957 was shortlisted for the Orwell Prize in 2014. The Cultural Revolution: $A$ People's History, 1962-1976 is the last volume in his trilogy on the Mao era and was published in early May 2016.

\begin{abstract}
摘要: 这篇论文利用了新的资料库證据, 来證明文革晚期存在著繁多零散的 抵抗行动，最终颠覆了规划经济。在这个鲜有人留意到的现象里，村民重新 和市场连繫起来，这些村民由腹地里最贫困的地方以至沿岸较富庶的地方 都有。这场静默的革命直捣社会的架构, 地方幹部对此往往无奈默许, 甚至 推波助澜。总括而言, 论文提出背後真正策划经济改革的, 是人民, 而不是 邓小平, 和中欧和苏联的领导一样, 他不过是别无选择下, 随大势所趋行事。

关键词: 中国; 文革; 规划经济; 非集体化; 市场
\end{abstract}

\section{References}

Bonnin, Michel. 2013. The Lost Generation: The Rustification of China's Educated Youth (19681980). Hong Kong: Chinese University of Hong Kong Press.

Bramall, Chris. 1995. "Origins of the agricultural 'miracle': some evidence from Sichuan." The China Quaterly 143, 731-755.

Huang, Shu-min. 1989. The Spiral Road: Change in a Chinese Village through the Eyes of a Communist Party Leader. Boulder, CO: Westview Press.

Kelliher, Daniel. 1992. Peasant Power in China: The Era of Rural Reform, 1979-1989. New Haven, CT: Yale University Press.

Kueh, Y. Y. 2006. "Mao and agriculture in China's industrialization: three antitheses in a 50-year perspective." The China Quarterly 187, 700-723.

Rév, Istvan. 1987. "The advantages of being atomized: how Hungarian peasants coped with collectivization." Dissent 34(3), 341-45.

Rittersporn, Gábor T. 2014. Anguish, Anger, and Folkways in Soviet Russia. Pittsburgh, PA: University of Pittsburgh Press.

Thaxton, Ralph. 2008. Catastrophe and Contention in Rural China: Mao's Great Leap Famine and the Origins of Righteous Resistance in Da Fo Village. Cambridge: Cambridge University Press.

White, Lynn T. 1998. Unstately Power: Local Causes of China's Economic Reforms. Armonk, NY: M.E. Sharpe.

Yang, Dali. 1996. Calamity and Reform in China: State, Rural Society, and Institutional Change since the Great Leap Famine. Stanford, CA: Stanford University Press.

Zhou, Kate. 1996. How the Farmers Changed China: Power of the People. Boulder, CO: Westview Press.

Zweig, David. 1989. Agrarian Radicalism in China, 1968-1981. Cambridge, MA: Harvard University Press. 